\title{
MICROORGANISMS OF GRAPE BERRIES
}

\author{
Attila Kántor ${ }^{1, \#, ~ J a ́ n ~ M a r e c ̌ e k ~}{ }^{1}$, Eva Ivanišová ${ }^{1}$, Margarita Terentjeva ${ }^{2}$, \\ and Miroslava Kačániová ${ }^{3,4}$
}

\author{
${ }^{1}$ Department of Plant Storage and Processing, Faculty of Biotechnology and Food Sciences, Slovak University of Agriculture, \\ Tr. A. Hlinku 2, SLOVAKIA \\ 2 Institute of Food and Environmental Hygiene, Faculty of Veterinary Medicine, Latvia University of Agriculture, \\ 8 K. Helmana Str., Jelgava, LV-3004, LATVIA \\ ${ }^{3}$ Department of Microbiology, Faculty of Biotechnology and Food Sciences, Slovak University of Agriculture, \\ Tr. A. Hlinku 2, Nitra, SLOVAKIA \\ ${ }^{4}$ Department of Bioenergy and Food Technology, Faculty of Biology and Agriculture, University of Rzeszow, \\ Zelwerowicza St. 4, Rzeszow, POLAND \\ \#Corresponding author, kantor.spu@gmail.com
}

Communicated by Aivars Bērziṇš

Grape surface is an unstable habitat that changes greatly according to the stage of grape ripening. Different bacteria and yeasts can colonise the surface of grape berry and the diversity of microorganisms depends on the stage of ripening, pesticide application and health condition. The aim of this study was to study the microflora of the surface of grape berries. Altogether, 19 grape samples from Slovakia were collected. The spread plate method was applied and a $100 \mu \mathrm{L}$ inoculum of each dilution $\left(10^{-2}, 10^{-3}\right)$ was plated on TSA, MEA, and MRS agar for isolation of microorganisms from grapes. Proteins were extracted from cells by ethanol/formic acid extraction procedure. MALDI-TOF Mass Spectrometry was used for identification of microorganisms. In total, 11 genera of Gram-negative bacteria, 11 of Gram-positive bacteria and nine of yeasts were identified. Among 200 isolates, Gram-negative, Gram-positive bacteria and yeasts represented $11 \%, 27 \%$ and $62 \%$ of the total number of isolates studied. The most common genera of isolated yeasts were Hanseniaspora (37\%), Metschnikowia (31\%), and Rhodotorula (10\%). The most frequently isolated among Gram-negative bacteria were Acinetobacter (22\%), Pseudomonas (22\%) and Sphingomonas (13\%). The most common genera of Gram-positive bacteria were Bacillus (20\%), Lactobacillus (19\%), Leuconostoc and Staphylococcus (11\%), respectively.

Key words: grape berries, microorganisms, isolation and identification, MALDI-TOF Mass Spectrometry.

\section{INTRODUCTION}

The presence of yeasts and bacterial species on grape berry surfaces varies at the quantitative and qualitative levels as functions of several factors (Fleet et al., 2002; Tournas and Katsoudas, 2005; Valero et al., 2005; Raspor et al., 2006; Barata et al., 2012). Grape berry surface is an unstable habitat that changes greatly according to the stage of grape ripening, which is itself dependent on several environmental factors, such as: rapid changes in temperature, humidity and UV radiation, nutritive limitations, and the application of agrochemical treatments (Pretorius 2000; Comitini and Ciani 2008; Chavan et al., 2009; Čadež et al., 2010; Li et al., 2010; Cordero-Bueso et al., 2011). The study of the microbial communities of grapes is usually addressed to berries, being well established that mature grapes harbour microbial populations at levels of $10^{4}-10^{6} \mathrm{CFU} / \mathrm{g}$ consisting mostly of yeasts and various species of lactic and acetic acid bacteria (Fleet, 2003). Regarding yeasts, oxidative basidiomycetous yeasts, without any enological interest, like Sporobolomyces, Cryptococcus, Rhodotorula, Filobasidium spp. and Aureobasidium pullulans are mostly prevalent in the vineyard environment (soil, bark, leaves, grapes) (Subden et al., 2003; Prakitchaiwattana et al., 2004; Renouf et al., 2005). Among the ascomycetes, apiculate fermentative yeasts (Hanseniaspora uvarum [teleomorph] Kloeckera apiculata [anamorph]) and oxidative yeasts (mostly genus Candida, Pichia and Metschnikowia) are predominant on ripe grapes (Davenport 1974; Sabate et al., 2002; Jolly et al., 2003; Subden et al., 2003; Prakitchaiwattana et al., 2004; Renouf et al., 2005). However, the microbial ecology of damaged grapes has been poorly studied and it is not clear if damaged grapes are significant vehicles of dangerous spoilage microorganisms (Loureiro and MalfeitoFerreira, 2003). Several factors affect the dissemination of yeasts on the berry surface and berry rupture is associated with a sudden increase in microbial load to more than $10^{6}$ CFU/g (Fleet, 2003). More recent investigations have stud- 
ied the diversity of the grapevine endophytic bacteria, and have shown that Pseudomonas and Bacillus, can act as biological disease suppression agents, stimulating plant growth and health (Bulgari et al., 2009; West et al., 2010; Compant et al., 2011). Most research has concentrated on bacteria of oenological interest, like acetic and lactic acid bacteria present in the microflora on grape berries (Barbe et al., 2001; Bae et al., 2006; Nisiotou et al., 2011). Little information is available about the effects of epiphytic bacteria on other plant parts, like leaves and bark. Despite their importance, the diversity of epiphytic bacteria on grape berries remains poorly described, as is the role of other plant parts and vineyard soil in bacterial colonisation. Soil microorganisms are able to colonise parts of the plant above the ground, including leaves and fruit (Rekah et al., 2000; Compant et al., 2010). The surface of grape berries represents a natural habitat for bacterial microbiota that has various impacts on the sanitary quality of grapes (Verginer et al., 2010).

The aim of this study was to study the microflora of the surface of grape berries and identify microorganisms by MALDI-TOF Mass Spectrometry.

\section{MATERIAL AND METHODS}

Grape samples. Nineteen grape samples were used in this study. Ripe grape bunches were collected into sterile polyethylene bags and stored at $8-10{ }^{\circ} \mathrm{C}$ for $24 \mathrm{~h}$ until the next microbiological analysis. The grape samples were collected from the Central Slovakian wine region $(n=12)$, Nitra wine region $(n=4)$ and Tokaj wine region $(n=3)$. We investigated grape samples of the following varieties: Rheinriesling $(n=1)$, Welschriesling $(n=2)$, Furmint $(n=1)$, Lipovina $(n=1)$, Moravian Muscat $(n=1)$, Pálava $(n=1)$, Pinot Blanc $(n=1)$, Pinot Gris $(n=1)$, Grüner Veltliner $(n=1)$, Cabernet Sauvignon $(n=1)$, Blue Frankish $(n=5)$, Blue Portugal $(n=1)$, Merlot $(n=1)$ and Pinot Noir $(n=1)$.

\section{Microbiological examination and cultivation conditions.} Fifty berries from each grape variety were diluted with 50 $\mathrm{ml}$ sterile physiological saline $(0.85 \%)$. Berries were stirred on a horizontal shaker for 15 minutes. After that dilutions $10^{-2}$ and $10^{-3}$ were prepared and used. The spread plate method was used for isolation of yeasts in wine samples and $0.1 \mathrm{ml}$ of each dilution $\left(10^{-2}, 10^{-3}\right)$ was placed on the surface of a solidified cultivation medium. Yeast was cultivated on Malt extract agar base (MEA) (BioMark ${ }^{\circledR}$, India) supplemented with glucose $(20 \mathrm{~g} / \mathrm{l})\left(\right.$ Centralchem $^{\circledR}$, Slovakia), yeast extract (3 g/l) (Conda, Spain) and bromocresol green $(0.020 \mathrm{~g} / \mathrm{l})\left(\right.$ Centralchem ${ }^{\circledR}$, Slovakia). Yeasts were cultivated on Petri dishes at $25{ }^{\circ} \mathrm{C}$ for five days in aerobic conditions and randomly picked colonies (macroscopic morphological differences) were re-streaked into new agar plates. Bacteria were counted and cultivated on TSA (Tryptic Soya agar, HiMedia ${ }^{\circledR}$ ) and Lactobacillus MRS (de Man, Rogosa and Sharpe, HiMedia ${ }^{\circledR}$ ) agar medium. Bacterial cells were cultivated at $30{ }^{\circ} \mathrm{C}$ for $48 \mathrm{~h}$ (TSA) and $72 \mathrm{~h}$ (MRS), respectively. After cultivation, proteins were extracted from fresh yeast and bacterial colonies.
MALDI-TOF Mass Spectrometry. MALDI-TOF MS model Microflex LT/SH biotyper (Bruker Daltonics, Germany, Bremen) was used for identification of bacteria isolated from the red and white wine samples. After cultivation (at $30{ }^{\circ} \mathrm{C}$ for $2-3$ days), isolated colonies were picked up from cultivation media (TSA, MRS) and suspended in 300 $\mu \mathrm{l}$ of sterile distilled water and mixed thoroughly. $900 \mu \mathrm{lab}-$ solute ethanol (99\%, Sigma-Aldrich, USA) was added. The mixture was centrifuged at $13000 \times \mathrm{g}$ for $2 \mathrm{~min}$. After that, supernatant was discarded, and the pellet was centrifuged again. Residual ethanol was completely removed by pipetting and the pellet was allowed to dry at a room temperature. Subsequently $10 \mu \mathrm{l}$ formic acid (70\%, Sigma-Aldrich, USA) was added and mixed with the pellet with a sterile toothpick. Next, $10 \mu \mathrm{l}$ acetonitrile (100\%, Sigma-Aldrich, USA) was added and mixed thoroughly. The solution was centrifuged at maximum speed for 2 minutes again, and $1 \mu \mathrm{l}$ of the supernatant was spotted on a polished MALDI target plate (Bruker Daltonics, Germany). Immediately after drying $1 \mu \mathrm{l}$ of the matrix solution was added to each spot and allowed to air dry. The matrix used was a saturated solution of HCCA: i-cyano-4-hydroxycinnamic acid (Bruker Daltonics, Germany) dissolved in 50\% acetonitrile with $0.025 \%$ trifluoroacetic acid (TFA) (100\%, Sigma-Aldrich, USA). The matrix solution preparation $(2.5 \mathrm{mg}$ of HCCA) contained $500 \mu \mathrm{l}$ acetonitrile, $475 \mu \mathrm{l}$ ultrapure water and $25 \mu \mathrm{l}$ trifluoroacetic acid. Then $2.5 \mathrm{mg}$ HCCA was added to 250 $\mu \mathrm{l}$ of this solution. Samples were then processed in a MALDI-TOF MS (Microflex LT/SH, Bruker Daltonics, Germany, Bremen) with flex Control software v3.4 and the results obtained were analysed with Realtime Classification software (RTC) v3.1 (Bruker Daltonics, Germany). Each spectrum was obtained by averaging 240 laser shots acquired in automatic mode at the minimum laser power necessary for ionisation of the samples. The spectra were analyzed in an $\mathrm{m} / \mathrm{z}$ range of 2 to $20 \mathrm{kDa}$ (Pavlovic et al., 2014; Van Veen et al., 2010; Marklein et al., 2009).

\section{RESULTS}

We identified from the surface of grape berries 51 species of bacteria belonging to 22 genera (11 gram-negative and 11 gram-positive) and 14 species of yeast belonging to 9 genera with MALDI-TOF Mass Spectrometry. The percentage representation of each group (gram-negative $\mathrm{G}^{-}$, grampositive bacteria $\mathrm{G}^{+}$and yeasts) reached the following values: 23 isolates $\left(\mathrm{G}^{-}\right)(11 \%), 54$ isolates $\left(\mathrm{G}^{+}\right)(23 \%)$, and 123 isolates of yeasts $(62 \%)$ from a total of 200 isolates. Table 1 indicates that the most common microorganisms isolated from grapes were yeasts. The highest number of yeast species were identified from grape varieties Blue Frankish (19\%), Cabernet Sauvignon (10\%), and Welschriesling $(10 \%)$. Yeast was isolated from each grape variety. Bacterial species were identified in lower counts and not isolated from four grape varieties for $\mathrm{G}^{-}$bacteria and from two grape varieties for $\mathrm{G}^{+}$bacteri. The most common yeast species were Hanseniaspora uvarum (37\%) and Metschnikowia pulcherrima $(31 \%)$. These two yeasts were isolated from 12 
Table 1

NUMBER OF MICROBIAL SPECIES IN DIFFERENT GRAPE VARIETIES

\begin{tabular}{lccccc}
\hline \multicolumn{1}{c}{ Grape variety } & $\mathrm{G}^{-}$bacteria & $\mathrm{G}^{+}$bacteria & Yeasts & Total \\
\hline Cabernet Sauvignon & 0 & 0 & 12 & 12 \\
Blue Frankish & 6 & 13 & 23 & 42 \\
Furmint & 0 & 1 & 7 & 8 \\
Lipovina & 0 & 0 & 6 & 6 \\
Merlot & 1 & 5 & 7 & 13 \\
Blue Portugal & 3 & 3 & 5 & 11 \\
Moravian Muscat & 1 & 3 & 5 & 9 \\
Pálava & 0 & 1 & 8 & 9 \\
Rheinriesling & 1 & 1 & 9 & 11 \\
Welschriesling & 1 & 4 & 13 & 18 \\
Pinot Blanc & 1 & 1 & 6 & 8 \\
Pinot Noir & 5 & 8 & 6 & 19 \\
Pinot Gris & 2 & 11 & 6 & 19 \\
Grüner Veltliner & 2 & 3 & 10 & 15 \\
Total & 23 & 54 & 123 & 200 \\
& & & &
\end{tabular}

(M. pulcherrima) and 11 (H. uvarum) grape varieties (total 14). M. pulcherrima was not identified in Pinot Noir and Pinot Gris grapes and H. uvarum was not recorded in Pinot Noir, Pinot Gris and Grüner Veltliner. The number of species of the three main groups of microorganisms in different grape varieties are given in Table 1.

Eleven gram-negative bacterial genera were identified by MALDI-TOF. Percentage of the number of isolates of each genus is shown in Figure 1 for $\mathrm{G}^{-}$on Figure 2 for $\mathrm{G}^{+}$and on Figure 3 for yeast. It was very interesting that the highest percentage of isolates for $\mathrm{G}^{-}$bacteria was for Acinetobacter (Acinetobacter junii 13\%) and Pseudomonas with 22\%, Sphingomonas (13\%), Cupriavidus and Stenotrophomonas with $9 \%$. We identified 17 different species of $\mathrm{G}^{-}$bacteria, and 34 different species of $\mathrm{G}^{+}$bacteria. The highest percentage representation (of isolates) belonged to genus Bacillus (20\%) and Lactobacillus (19\%), and also the most species were in these two genera. We identified Bacillus cereus (2\%), B. megaterium (9\%), B. niacini (2\%), B. pumilus (2\%), B. safensis (4\%), B. simplex (2\%), Lactobacillus acidophilus (2\%), L. fermentum (4\%), L. nageli (2\%), L. oris (2\%), L. saerimneri (2\%), and L. paracasei (6\%). The highest percentage representation (isolates) by species in $\mathrm{G}^{+}$ bacteria belongs to Leuconostoc mesenteroides spp. mesenteroides with $11 \%$, followed by Micrococcus luteus (9\%), Bacillus megaterium (9\%), and Lactobacillus paracasei (6\%). Staphylococcus (11\%), Microbacterium (9\%), and Arthrobacter (9\%) were also present with high species number (five species from each of these three genera).

Yeasts are very important for winemaking. They are present on the grape skin as a natural microflora. The composition of yeast species on grapes depends on factors like temperature, soil, rain, insects, pesticide treatments and grape variety. The most common yeast species associated with grapes were Hanseniaspora uvarum (37\%) and Metschnikowia

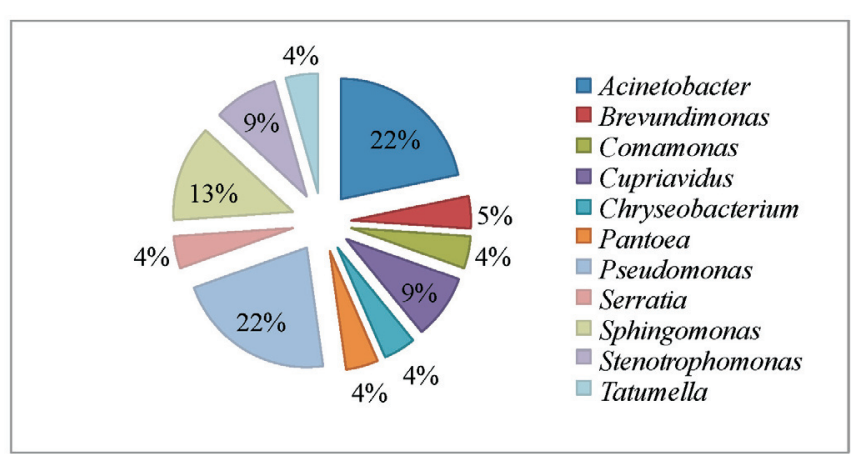

Fig. 1. Percentage of number of isolates of genera of Gram-negative bacteria.

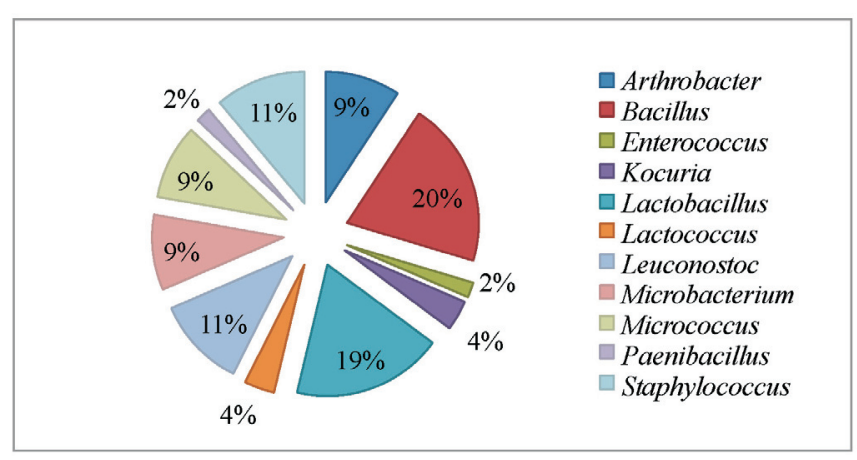

Fig. 2. Percentage of number of isolates of genera of Gram-positive bacteria.

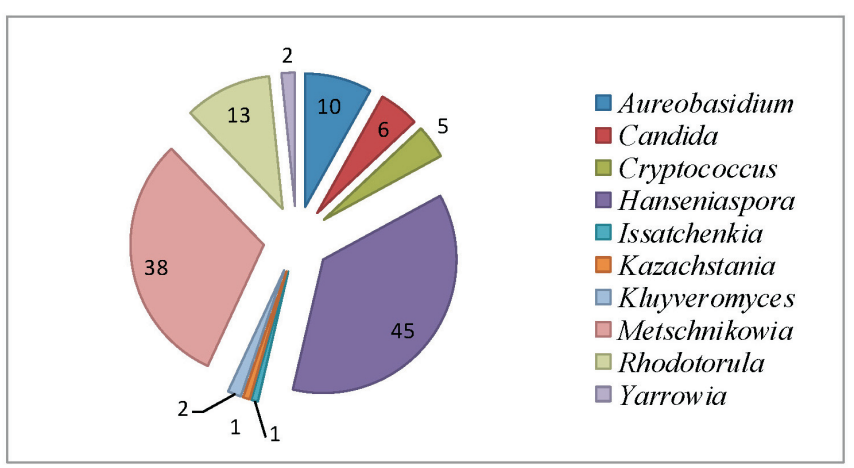

Fig. 3. Percentage of number of isolates of genera of yeasts.

pulcherrima (31\%). In our study we identified these yeasts in high numbers. Rhodotorula (10\%) species were also very common, but they have no significance in winemaking. Candida was another very common genus on grapes of highly diverse yeasts, and was represented by three species: Candida saitoana, Candida magnolia, and Candida parapsilosis. The last one is also a normal human commensal species and is very often isolated from human skin. Very rare species of yeast in this study were Kazachstania exigua, Issatchenkia orientalis, Yarrowia lipolytica, and Kluyveromyces marxianus.

Grapes also bear a wide diversity of bacterial species common in nature or in other food related environments. Table 2 present the results from identification of microorganisms by MALDI-TOF MS. In total we identified 65 species of bacteria and yeast from 19 Slovakian grapes. Seventeen $\mathrm{G}^{-}$ 
NUMBER OF ISOLATES OF MICROORGANISMS IDENTIFIED BY MALDI-TOF

\begin{tabular}{|c|c|c|c|}
\hline Microorganisms & $\begin{array}{l}\text { White } \\
\text { grape }\end{array}$ & $\begin{array}{l}\text { Blue } \\
\text { grape }\end{array}$ & $\begin{array}{c}\text { Total } \\
\text { number }\end{array}$ \\
\hline Gram-negative bacteria & 8 & 15 & 23 \\
\hline Acinetobacter junii & 1 & 2 & 3 \\
\hline Acinetobacter lwoffii & 0 & 1 & 1 \\
\hline Acinetobacter ursingii & 0 & 1 & 1 \\
\hline Brevundimonas vesicularis & 0 & 1 & 1 \\
\hline Comamonas nitrativorans & 0 & 1 & 1 \\
\hline Cupriavidus necator & 1 & 0 & 1 \\
\hline Cupriavidus pauculus & 0 & 1 & 1 \\
\hline Chryseobacterium scophthalmum & 0 & 1 & 1 \\
\hline Pantoea dispersa & 1 & 0 & 1 \\
\hline Pseudomonas asplenii & 0 & 1 & 1 \\
\hline Pseudomonas frederiksbergensis & 0 & 1 & 1 \\
\hline Pseudomonas kilonensis & 1 & 1 & 2 \\
\hline Pseudomonas sp. & 0 & 1 & 1 \\
\hline Serratia marcescens & 0 & 1 & 1 \\
\hline Sphingomonas sp. & 3 & 0 & 3 \\
\hline Stenotrophomonas maltophilia & 0 & 2 & 2 \\
\hline Tatumella terrea & 1 & 0 & 1 \\
\hline Gram-positive bacteria & 25 & 29 & 54 \\
\hline Arthrobacter tumbae & 0 & 1 & 1 \\
\hline Arthrobacter citreus & 1 & 0 & 1 \\
\hline Arthrobacter koreensis & 1 & 0 & 1 \\
\hline Arthrobacter parietis & 1 & 0 & 1 \\
\hline Arthrobacter ramosus & 0 & 1 & 1 \\
\hline Bacillus cereus & 0 & 1 & 1 \\
\hline Bacillus megaterium & 2 & 3 & 5 \\
\hline Bacillus niacini & 1 & 0 & 1 \\
\hline Bacillus pumilus & 0 & 1 & 1 \\
\hline Bacillus safensis & 0 & 2 & 2 \\
\hline Bacillus simplex & 1 & 0 & 1 \\
\hline Enterococcus moraviensis & 0 & 1 & 1 \\
\hline Kocuria palustris & 0 & 1 & 1 \\
\hline Kocuria rosea & 1 & 0 & 1 \\
\hline
\end{tabular}

bacteria species identified belonged to 11 genera and 9 families: Burkholderiaceae (9\%), Caulobacteraceae (4\%), Comamonadaceae (4\%), Enterobacteriaceae (13\%), Flavobacteriaceae (4\%), Moraxellaceae (22\%), Pseudomonadaceae (22\%), Sphingomonadaceae (13\%), and Xanthomonadaceae $(9 \%)$. More than thirty (total 34 species) $\mathrm{G}^{+}$ bacteria species belonged to 9 families: Bacillaceae (20\%), Enterococcaceae (2\%), Lactobacillaceae (19\%), Leuconostocaceae (11\%), Microbacteriaceae (9\%), Micrococcaceae (22\%), Paenibacillaceae (2\%), Staphylococcaceae $(11 \%)$, and Streptococcaceae (4\%). Yeasts were the most common isolated group of microorganisms from grapes. In total we identified 123 isolates of yeasts, which included 14 species of 9 genera and 5 families (incertae sedis - Rhodotorula). The percentage representation of yeast families by isolates were as follows: Dothioraceae (8\%), incertae sedis (11\%), Metschnikowiaceae (31\%), Pichiaceae (1\%), Saccharomycetaceae (45\%), and Tremellaceae (4\%).
Lactobacillus acidophilus

Lactobacillus fermentum

Lactobacillus nageli

Lactobacillus oris

Lactobacillus paracasei

Lactobacillus saerimneri

Lactococcus lactis

Leuconostoc mesenteroides ssp.

mesenteroides

Microbacterium arborescens

Microbacterium foliorum

Microbacterium maritypicum

Microbacterium oleivorans

Microbacterium oxydans

Micrococcus luteus

Paenibacillus pabuli

Staphylococcus epidermidis

Staphylococcus equorum ssp.

equorum

Staphylococcus hominis

Staphylococcus saprophyticus

Staphylococcus warneri

Yeasts

Aureobasidium pullulans

Candida magnoliae

Candida parapsilosis

Candida saitoana

Cryptococcus diffluens

Cryptococcus magnus

Hanseniaspora uvarum

Issatchenkia orientalis

Kazachstania exigua

Kluyveromyces marxianus

Metschnikowia pulcherrima

Rhodotorula glutinis

Rhodotorula mucilaginosa

Yarrowia lipolytica

Total

\section{DISCUSSION}

The surface of grape berries represents a complex natural reservoir of bacterial microbiota originating from the surrounding environment (Zarraonaindia et al., 2015). Grapevine bacteria play a key role not only in plant health, but also in crop quality and yields, which can influence the winemaking process (Verginer et al., 2010; Nisiotou et al., 2011). According to Portillo et al. (2015) the diversity of epiphytic bacteria on grape berries remains poorly described. Numerous studies have analysed the presence of yeast on the surface of grapes (de Andrés-de Prado et al., 2007; Fleet, 1990) and many have indicated that Saccharomyces cerevisiae is present only in very small numbers on healthy grapes (Martini, 1993; Pretorius, 2000). The most frequently isolated native species is Kloeckera apiculata, which may account for more than $50 \%$ of the total yeast 
flora recovered from fruit. Lesser numbers of other yeasts, such as species of Aureobasidium, Candida, Cryptococcus, Kluyveromyces, Metschnikowia, Pichia, and Rhodotorula, have also been reported (Fleet, 1990; Velázquez et al., 1991; Sabate et al., 2002). Aureobasidium (8\% in our study) is a common black yeast-like fungus that can produce the polysaccharide "pullulan" (Singh et al., 2012). Saccharomyces can be found in grape musts, but the populations are often less than $50 \mathrm{CFU} / \mathrm{ml}$ (König et al., 2009). We did not isolate Saccharomyces cerevisiae in our study. In good agreement with the findings of many other authors (Fleet $e t$ al., 2002; Deak, 2007; Barata et al., 2012), H. uvarum was the most abundant species on grapes, which means that on average it gave rise to more colonies per grape sample than any other species. According to several authors a new species belonging to the genus Metschnikowia, M. viticola, was isolated from grapes in Hungary (Peter et al., 2005) and many new species have recently been described in the Metschnikowia pulcherrima clade. These include $M$. chrysoperlae (Suh et al., 2004), M. fructicola (Kurtzman and Droby, 2001) and M. andauensis (Molnar and Prillinger, 2005). Most research has concentrated on bacteria of oenological interest, like acetic acid and lactic acid bacteria (LAB) present in the microbiota on grape berries (Bae et al., 2006; Nisiotou et al., 2011). Acetic acid bacteria are usually related with spoilage of wine and Oenococcus oeni and some other LAB species are known to perform malolactic fermentation or to promote spoilage of wine depending on the species or strain. We did not isolate acetic acid bacteria from the surface of grapes used in this study. Bokulich et al. (2012) studied the diversity of microorganisms in spoiled wine with Botrytis cinerea, using molecular genetic methods involving PCR and subsequent sequencing of amplicons, and found that the genera Acetobacter, Gluconobacter, Gluconacetobacter were dominant and the second most represented group was order Lactobacillales. In the range of $1-10 \%$ of the identified species, they identified the following genera of microorganisms: Chryseobacterium, Methylobacterium, Sphingomonas, Arcobacter, Naxibacter, Ralstonia, Frigoribacterium, Pseudomonas, Acinetobacter, and Zymobacter. From these genera, we identified Acinetobacter (22\%), Chryseobacterium (4\%), Sphingomonas (13\%) and Pseudomonas (22\%) by using MALDI-TOF MS. Acinetobacter is a genus of gram-negative bacteria normally present in the soil, water, and also part of the natural microflora of humans (Towner, 2006). Chryseobacterium and Sphingomonas (Balkwill et al., 2006) formed orange colonies, and well distinguishable from other less expressive species on a petri dish. The yeast populations of grapes generally comprise between $10^{2}$ and $10^{4}$ cells/g (Fleet et al., 2002), but higher values have also been reported. Hanseniaspora uvarum appears to be the most common grape berry species worldwide, which is consistent with its predominance in the beginning of spontaneous must fermentations. Like yeasts, lactic acid bacteria are also present in vineyards. Species that have been isolated from grapes include Lactobacillus hilgardii, L. plantarum, L. casei, Oenococcus oeni, Leuconostoc mesenteroides, and Pediococcus damnosus (Lonvaud-Funel et al., 1999). Ace- tic acid bacteria are commonly associated with grapes and are normally present in wine must. Unspoiled grapes are reported to have $10^{2}-10^{3} \mathrm{CFU} / \mathrm{g}$ acetic acid bacteria, whereas spoiled and damaged grape can contain more than $10^{6}$ CFU/g (Bartowsky, 2009). In cases of mould growth, particularly of Botrytis cinerea, grape damage can cause development of populations and diversity of acetic acid bacteria, not only of $G$. oxydans but also of A. aceti or A. pasteurianus. González et al. (2006) reported a major presence of both $G$. oxydans and A. aceti in spoiled grapes. Concerning bacterial species, acetic acid bacteria are regarded as innocent because they are easily controllable in the winery, although the exaggerated production of acetic acid during grape sour rot is a serious threat to wine quality. The physiological diversity of lactic acid bacteria does not allow a precise assessment of their technological significance. The typical agent of malolactic fermentation is $O$. oeni, while Lactobacillus spp. and Pediococcus spp. may be responsible for spontaneous fermentations (Lerm et al., 2010). These species may spoil wine when their activity goes beyond malic conversion, particularly in high $\mathrm{pH}$ wines, producing off flavours or biogenic amines (Arena et al., 2011; Capozzi et al., 2011; Pan et al., 2011).

\section{CONCLUSIONS}

We identified 65 species of bacteria and yeast by MALDITOF Mass Spectrometry. Microbiological analysis was conducted for nineteen grape samples. In total, 200 isolates were analysed by MALDI-TOF. From white grapes $103 \mathrm{mi}-$ croorganisms were isolated and 97 from blue grape varieties. The three main groups of microorganisms were investigated in this study. We identified 17 species of gramnegative and 34 species of gram-positive bacteria, and 14 species of yeasts.

\section{ACKNOWLEDGEMENTS}

This work has been supported by grant of European Community under project No. 26220220180: Building Research Centre "AgroBioTech" and by grant of Slovak Research and development Agency No. VEGA 1/0411/17.

\section{REFERENCES}

Andriy, A. S., Andriy, Y. V. (2009). Candida famata (Debaryomyces hansenii). In: Satyanarayana, T., Kunze, G. (eds.). Yeast Biotechnology: Diversity and Applications. Springer, Netherlands, pp. 85-111.

Arena, M. P., Romano, A., Capozzi, V., Beneduce, L., Ghariani, M., Grieco, F., Lucas, P., Spano, G. (2011). Expression of Lactobacillus brevis IOEB 9809 tyrosine decarboxylase and agmatine deaminase genes in wine correlates with substrate availability. Lett. Appl. Microbiol., 53, 395-402.

Bae, S., Fleet, G. H., Heard, G. M. (2006). Lactic acid bacteria associated with wine grapes from several Australian vineyards. J. Appl. Microbiol., 100, 712-727.

Balkwill, D. L., Fredrickson, J. K., Romine, M. F. (2006). Sphingomonas and related genera. In: Dworkin, M. et al. (eds.). The Prokaryotes. Springer Verlag, New York, pp. 605-629.

Barata, A., Malfeito-Ferreira, M., Loureiro, V. (2012). The microbial ecology of wine grape berries. Int. J. Food Microbiol., 153, 253-259. 
Barbe, J. C., De Revel, G., Joyeux, A., Bertrand, A., Lonvaud-Funel, A. (2001). Role of botrytized grape microorganisms in $\mathrm{SO}_{2}$ binding phenomena. J. Appl. Microbiol., 90, 34-42.

Bartowsky, E. J. (2009). Bacterial spoilage of wine and approaches to minimize it. Lett. Appl. Microbiol., 48, 149-156.

Beltran, G., Torija, M. J., Novo, M., Ferrer, N., Poblet, M., Guillamon, J. M., Rozes, N., Mas, A. (2002). Analysis of yeast populations during alcoholic fermentation: A six year follow-up study. Syst. Appl. Microbiol., 25, 287-293

Bokulich, N. A., Joseph, C. M., Allen, G., Benson, A. K., Mills, D. A. (2012). Next-generation sequencing reveals significant bacterial diversity of botrytized wine. PLoS One, 7(e), 36357.

Bulgari, D., Casati, P., Brusetti, L., Quaglino, F., Brasca, M., et al. (2009). Endophytic bacterial diversity in grapevine (Vitis vinifera L.) leaves described by $16 \mathrm{~S}$ rRNA gene sequence analysis and length heterogeneity-PCR. J. Microbiol., 47, 393-401.

Čadež, N., Zupan, J., Raspor, P. (2010). The effect of fungicides on yeast communities associated with grape berries. Federation of European Microbial Societies (FEMS) Yeast Res., 10, 619-630.

Capozzi, V., Ladero, V., Beneduce, L., Fernandez, M., Alvarez, M. A., Benoit, B., Laurent, B., Grieco, F., Spano, G. (2011). Isolation and characterization of tyramine-producing Enterococcus faecium strains from red wine. Food Microbiol., 28, 434-439.

Chavan, P., Mane, S., Kulkarni, G., Shaikh, S., Ghormade, V., Nerkar, D. P., Shouche, Y., Deshpande, M. V. (2009). Natural yeast flora of different varieties of grapes used for wine making in India. Food Microbiol., 26, 801-808.

Clemente-Jimenez, J. M., Mingorance-Carzola, L., Martinez-Rodriguez, S., Las Heras-Vazquez, F. J., Rodriguez-Vico, F. (2004). Molecular characterization and oenological properties of wine yeasts isolated during spontaneous fermentation of six varieties of grape must. Food Microbiol., 21, $149-155$.

Combina, M., Mercado, L., Borgo, P., Elia, A., Joofre, V., Ganga, A., Martinez, C., Catania, C. (2005). Yeasts associated to Malbec grape berries from Mendoza, Argentina. J. Appl. Microbiol., 98, 1055-1061.

Comitini, F., Ciani, M. (2008). Influence of fungicide treatments on the occurrence of yeast flora associated with wine grapes. Ann. Microbiol., 58, 489-493.

Compant, S., Clément, C., Sessitsch, A. (2010). Plant growth-promoting bacteria in the rhizo and endosphere of plants: Their role, colonization, mechanisms involved and prospects for utilization. Soil Biol. Biochem., 42, 669-678.

Compant, S., Mitter, B., Colli-Mull, J. G., Gangl, H., Sessitsch, A. (2011). Endophytes of grapevine flowers, berries, and seeds: Identification of cultivable bacteria, comparison with other plant parts, and visualization of niches of colonization. Microb. Ecol., 62, 188-197.

Cordero-Bueso, G., Arroyo, T., Serrano, A., Tello, J., Aporta, I., Vélez, M. D. (2011). Influence of the farming system and vine variety on yeast communities associated with grape-berries. Int. J. Food Microbiol., 145, 132-139.

Csoma, H., Sipiczki, M. (2008). Taxonomic reclassification of Candida stellata strains reveals frequent occurrence of Candida zemplinina in wine fermentation. FEMS Yeast Res., 8, 328-336.

Davenport, R. R. (1974). Micro ecology of yeasts and yeast like organisms associated with an English vineyard. Vitis, 13, 123-130.

de Andrés-De Prado, R., Yuste-Rojas, M., Sort, X., Andrés Lacueva, C., Torres, M., Lamuela-Raventós, R. M. (2007). Effect of soil type on wines produced from Vitis vinifera $\mathrm{L}$. cv. Grenache in commercial vineyards. $J$. Agric. Food Chem., 55 (3), 779-786.

Deák, T. (2007). Handbook of Food Spoilage Yeasts. CRC Press. 352 pp.

Delfini, C., Gaia, P., Schellino, R., Strano, M., Pagliara, A., Ambró, S. (2002). Fermentability of grape must after inhibition with dimethyl dicarbonate (DMDC). J. Agric. Food Chem., 50, 5605-5611.
Fernández, M., Úbeda, J. F., Briones, A. I. (2000). Typing of nonSaccharomyces yeasts with enzymatic activities of interest in wine-making. Int. J. Food Microbiol., 59, 29-36.

Fleet, G. H. (1990). Growth of yeasts during wine fermentations. J. Wine Res., 1, 211-223.

Fleet, G. H. (2003). Yeast interactions and wine flavour. Int. J. Food Microbiol., 86, 11-22.

Fleet, G. H., Prakitchaiwattana, C. J., Beh, A. L., Heard, G. M. (2002). The yeast ecology of wine grapes. In: Ciani, M. (Ed.). Biodiv. Biotech. Wine Yeasts, 1-17.

Gonzáles, Á., Guillamón, J. M., Mas, A., Poblet, M. (2006). Application of molecular methods for routine identification of acetic acid bacteria. Int. J. Food Microbiol., 108, 141-146.

Hierro N, Gonzales, A., Mas, A., Guillamón, J. M. (2006). Diversity and evolution of non-Saccharomyces yeast populations during wine fermentation: Effect of grape ripeness and cold maceration. FEMS Yeast Res., 6, 102-111.

Ibarra, J. C., Ortiz-Gutiérrez, M., Alonso-Magana, P. (2004). Characterization of bromocresol green and resin as holographic film. Opt. Mater., 27, $567-572$.

Jolly, N., Augustyn, O., Pretorius, I. (2003). The occurrence of nonSaccharomyces cerevisiae yeast species over three vintages in four vineyards and grape musts from four production regions of the Western Cape, South Africa. S. Afr. J. Enol. Vitic., 24, 35-42.

König, H., Unden, G., Fröhlich, J. (eds.) (2009). Biology of Microorganisms on Grapes, in Must and in Wine. Springer-Verlag, Berlin Heidelberg. 522 pp.

Kourkoutas, Y., Dimitropoulou, S., Kanellaki, M., Marchant, R., Nigam, P., Banat, I. M., Koutinas, A. (2002). High-temperature alcoholic fermentation of whey using Kluyveromyces marxianus IMB3 yeast immobilized on delignified cellulosic material. Bioresour. Technol., 82, 177-181.

Kurtzman, C. P., Droby, S. (2001). Metschnikowia fructicola, a new ascosporic yeast with potential for biocontrol of postharvest fruit rots. Syst. Appl. Microbiol., 24, 395-399.

Lerm, E., Engelbrecht, L., Du Toit, M. (2010). Lactobacillus: The next generation of malolactic fermentation starter cultures: An overview. Food Bioprocess Tech., 4, 876-906.

Li, S. S., Cheng, C., Li, Z., Chen, J. Y., Yan, B., Han, B. Z., Reeves, M. (2010). Yeast species associated with wine grapes in China. Int. J. Food Microbiol., 138, 85-90.

Lonvaud-Funel, A. (1999). Lactic acid bacteria in the quality improvement and depreciation of wine. Ant. Van Leeuwen., 76, 317-331.

Loureiro, V., Malfeito-Ferreira, M. (2003). Spoilage yeasts in the wine industry. Int. J. Food Microbiol., 86, 23-50.

Marklein, G., Josten, M., Klanke, U., Müller, E., Horré, R., Maier, T., Wenzel, T., Kostrzewa, M., Bierbaum, G., Hoerauf, A., Sahl, H. G. (2009). Matrix-assisted laser desorption ionization-time of flight mass spectrometry for fast and reliable identification of clinical yeast isolates. J. Clin. Microbiol., 47 (9), 2912-2917.

Martini, A. (1993). Origin and domestication of the wine yeast Saccharomyces cerevisiae. J. Wine Res., 4, 165-176.

Martini, A., Ciani, M., Scorzetti, G. (1996). Direct enumeration and isolation of wine yeasts from grape surfaces. Amer. J. Enol. Vitic., 47, 435-440.

Molnar, O., Prillinger, H. (2005). Analysis of yeast isolates related to Metschnikowia pulcherrima using the partial sequences of the large subunit rDNA and the actin gene; description of Metschnikowia andauensis sp. nov. Syst. Appl. Microbiol. 28, 717-726.

Nisiotou, A. A., Rantsiou, K., Iliopoulos, V., Cocolin, L., Nychas, G. J. E. (2011). Bacterial species associated with sound and Botrytis-infected grapes from a Greek vineyard. Int. J. Food Microbiol., 145, 432-436.

Pan, W., Jussier, D., Terrade, N., Yada, R. Y., Mirade-Orduna, R. (2011). Kinetics of sugars, organic acids and acetaldehyde during simultaneous 
yeast-bacterial fermentations of white wine at different $\mathrm{pH}$ values. Food Res. Int., 44, 660-666.

Pavlovic, M., Mewes, A., Maggipinto, M., Schmidt, W., Messelhäußer, U., Balsliemke, J., Hörmansdorfer, S., Busch, U., Huber, I. (2014). MALDI-TOF MS based identification of food-borne yeast isolates. $J$. Microbiol. Methods, 106, 123-128.

Peter, G., Tornai-Lehoczki, J., Suzuki, M., Dlauchy, D. (2005). Metschnikowia viticola sp. nov., a new yeast species from grape. Ant. Van Leeuwen., 87, 155-160.

Portillo, Mdel C., Franqučs, J., Araque, I., Reguant, C., Bordons, A. (2015). Bacterial diversity of Grenache and Carignan grape surface from different vineyards at Priorat wine region (Catalonia, Spain). Int. J. Food Microbiol., 219, 56-63.

Prakitchaiwattana, C. J., Fleet, G. H., Heard, G. M. (2004). Application and evaluation of denaturing gradient gel electrophoresis to analyse the yeast ecology of wine grapes. FEMS Yeast Res., 4, 865-877.

Pretorius, I. S. (2000). Tailoring wine yeast for the new millennium: Novel approaches to the ancient art of winemaking. Yeast, 16, 675-729.

Quesada, M., Cenis, J. (1995). Use of random amplified polymorphic DNA in the characterization of wine yeasts. Amer. J. Enol. Vitic., 46 (2), 204-208.

Raspor, P., Milek, D. M., Polanc, J., Možina, S. S., Čadež, N. (2006). Yeasts isolated from three varieties of grapes cultivated in different locations of the Dolenjska vine growing region, Slovenia. Int. J. Food Microbiol., 109, 97-102.

Rekah, Y., Shtienberg, D., Katan, J. (2000). Disease development following infection of tomato and basil foliage by airborne conidia of the soilborne pathogens Fusarium oxysporum f. sp. radicis-lycopersici and $F$. oxysporum f. sp. basilici. Phytopathology, 90, 1322-1329.

Renouf, V., Claisse, O., Lonvaud-Funel, A. (2005). Understanding the microbial ecosystem on the grape berry surface through numeration and identification of yeast and bacteria. Aust. J. Grape Wine Res., 11, 316-327.

Renouf, V., Claisse, O., Lonvaud-Funel, A. (2007). Inventory and monitoring of wine microbial consortia. Appl. Microbiol. Biotech., 75, 149-164.

Sabate, J., Cano, J., Esteve-Zarzoso, B., Guillamón, J. M. (2002). Isolation and identification of yeasts associated with vineyard and winery by RFLP analysis of ribosomal genes and mitochondrial DNA. Microbiol. Res., 157, $267-274$

Received 5 October 2016

Accepted in the final form 16 November 2017
Singh, R., Gaur, R., Tiwari, S., Gaur, M. K. (2012). Production of pullulan by a thermotolerant Aureobasidium pullulans strain in non-stirred fed batch fermentation process. Braz. J. Microbiol., 43, 1042-1050.

Subden, R., Husnik, J., Van Twest, R., Van Der Merwe, G., Van Vuuren, H. (2003). Autochthonous microbial population in a Niagara Peninsula ice wine must. Food Res. Inter., 36, 747-751.

Suh, S. O., Gibson, C. M., Blackwell, M. (2004). Metschnikowia chrysoperlae sp. nov., Candida picachoensis sp. nov. and Candida pimensis sp. nov., isolated from the green lacewings Chrysoperla comanche and Chrysoperla carnea (Neuroptera: Chrysopidae). Int. J. Syst. Evol. Microbiol., 54, 1883-1890.

Torija, M. J., Rozes, N., Poblet, M., Guillamon, J. M., Mas, A. (2001). Yeast population dynamics in spontaneous fermentations: Comparison between two different wine-producing areas over a period of three years. Ant. Van Leeuwen., 79, 345-352.

Tournas, V. H., Katsoudas, E. (2005). Mould and yeast flora in fresh berries grapes and citrus fruits. Int. J. Food Microbiol., 105, 11-17.

Towner, K. (2006). The Genus Acinetobacter. In: Dworkin, M. et al. (eds.) The Prokaryotes. Springer Verlag, New York, pp. 746-758.

Valero, E., Schuller, D., Cambon, B., Casal, M., Dequin, S. (2005). Dissemination and survival of commercial wine yeast in the vineyard: A large scale, three-year study. FEMS Yeast Res., 5, 959-969.

Van Veen, S. Q., Claas, E. C. J., Kuijper, E. J. (2010). High-throughput identification of bacteria and yeast by matrix-assisted laser desorption ionization-time of flight mass spectrometry in conventional medical microbiology laboratories. J. Clin. Microbiol., 48 (3), 900-907.

Velázquez, J. B., Longo, E., Cansado, J., Villa, T. G., Sieiro, C., Calo, P. (1991). Improvement of the alcoholic fermentation of grape juice with mixed cultures of Saccharomyces cerevisiae wild strains. Negative effect of Kloeckera apiculata. World J. Microbiol. Biotech., 7, 485-489.

Verginer, M., Leitner, E., Berg, G. (2010). Production of volatile metabolites by grape-associated microorganisms. J. Agric. Food Chem., 58, 8344-8350.

West, E. R., Cother, E. J., Steel, C. C., Ash, G. J. (2010). The characterization and diversity of endophytes of grapevine. Can. J. Microbiol., 56, 209-216.

Zarraonaindia, I., Owens, S. M., Weisenhorn, P., West, K., HamptonMarcell, J., Lax, S., Bokulich, N. A., Mills, D. A., Martin, G., Taghavi, S., van der Lelie, D., Gilbert, J. A. (2015). The soil microbiome influences grapevine-associated microbiota. mBio, 6 (2), e02527-14.

\section{UZ VĪNOGU VIRSMAS ESOŠO MIKROORGANISMU RAKSTUROJUMS}

Vīnogu virsmas mikroflora ir daudzveidīga un mainās atkarībā no vīnogu gatavības pakāpes. Uz vīnogu virsmas var attīstīties dažādas baktērijas, raugi, un šo mikroorganismu daudzveidība dažādos vīnogu attīstības posmos ir atkarīga no to gatavības pakāpes, pesticīdu lietošanas biežuma un daudzuma, kā arī no auga veselības. Pētījuma mērḳis bija noteikt izplatītākos mikroorganismus, kas visbiežāk sastopami uz vīnogu virsmas. Pētījumos izmantoja Slovākijā augušus 19 vīnogu paraugus. Paraugi tika izmeklēti, izmantojot TSA, MEA un MRS agarus. Proteīnu ekstrahēšanai no mikroorganismu šūnām pielietoja etanola/ skudrskābes škīdumu. MALDI-TOF masas spektrometriju izmantoja mikroorganismu identifikācijai. Kopumā tika izolētas 11 gramnegatīvu, 11 grampozitīvu un 9 raugu ğintis. No iegūtiem 200 izolātiem, gramnegatīvas un grampozitīvas baktērijas, kā arī raugi attiecīgi veidoja 11, 27 un $62 \%$. Visbiežāk izolētās raugu sugas bija Hanseniaspora (37\%), Metschnikowia (31\%) un Rhodotorula (10\%). Savukārt biežāk izolētās gramnegatīvās baktērijas — Acinetobacter (22\%), Pseudomonas (22\%) un Sphingomonas (13\%). Visizplatītākās grampozitīvās baktēriju ǵintis bija Bacillus (20\%), Lactobacillus (19\%), Leuconostoc un Staphylococcus (11\%). 